\title{
GENETICAL SOCIETY OF GREAT BRITAIN
}

\section{ABSTRACTS of Papers read at the HUNDRED-AND-FIRST MEETING of the Society, held on WEDNESDAY, I6th NOVEMBER 1949, at the BIOMETRY DEPARTMENT, UNIVERSITY COLLEGE, Gower Street, London, W.C. I.}

THE GENETICS OF N-TYPE SHEEP

\author{
F. W. DRY \\ Massey College, New Zealand \\ and \\ A. S. FRASER \\ Institute of Animal Genetics, Edinburgh
}

The $\mathcal{N}$ and $n r$ genes were identified in the Romney Marsh breed, and presumably arose by mutation. Both genes condition a change in the parent breed, from the normal type which is hornless and has a longwool fleece, to the N-type, which is horned and has a carpet type of fleece. The $\mathcal{N}$ gene is a partial dominant which in $\mathcal{N} /+$ has an expression which overlaps with the normal range. The $n r$ gene is almost completely recessive. The two genes are non-allelomorphic. Preliminary analyses have been made of the genetics of modification of the expression of the $\mathcal{N}$ and $n r$ genes.

\section{"CRINKLED"-A NEW MUTANT IN THE HOUSE MOUSE, WITH DIVERSE EFFECTS ON THE SKIN AND HAIR \\ D. S. FALCONER, A. S. FRASER and J. W. B. KING Institute of Animal Genetics, Edinburgh}

A new mutant, which has been called " crinkled," was found in the progeny of mice treated with nitrogen mustard and has been the subject of genetical and developmental study. The mutant gene is a simple recessive and has shown no linkage with the genes $a, b, c^{c h}, \partial, p, s, b t, l x, R e$, and sex. The mutant phenotype shows a number of abnormalities of the skin and hair : the hairs are reduced in number and altered in structure; hairs are absent from the tail and from behind the ears : the tip of the tail is kinked : the eyelids are thickened : the ears of young mice have a peculiar shape : there is a change in the coloration of agouti animals : respiratory disorders are frequent. The majority of these abnormalities can be shown to be due to an abnormality in the development of the hair follicles, the period of development during which follicles normally form being very much shortened.

\section{CENTROMERE PRECOCITY IN LUZULA}

P. T. THOMAS

University College of Wales, Aberystwyth

In Luzula campestris and L. maxima (both with $2 \mathrm{n}=12$ ) the chromosomes pair normally at the prophase of meiosis and the bivalents each form one to three chiasmata. Contraction due to coiling occurs during prophase, but there is delay 
in attachment of nucleic acid on the chromosomes and there is also a corresponding delay in the disintegration of the nucleolus. The bivalents at diakinesis therefore appear "ghost" like although chromomeres can be clearly observed.

At metaphase the six paired configurations give the appearance of ring quadrivalents with parallel co-orientation or they could be interpreted as bivalents with diffuse centromeres (as de Camara has done for Luzula purpurea). But closer study has shown that the unusual appearance of the bivalents is due to a precocious division of the centromeres. Following rapid attachment of nucleic acid at the end of prophase the centromeres are seen to have divided. The bivalents "open out" into ring-like configurations in each of which 4 centromeres are co-orientated on a metaphase plate. Sometimes the separation between daughter centromeres at metaphase I. is so complete that two detached half bivalents can be observed side by side.

The consequences of this behaviour will be discussed and also the significance of these observations in relation to a possible explanation for the phenomenon of brachymeiosis in fungi.

\title{
HYBRIDS BETWEEN SOME MEMBERS OF THE RASSENKREIS TRITURUS CRISTATUS
}

\author{
H. SPURWAY \\ Biometry Department, University College, London \\ and \\ H. G. CALLAN \\ Institute of Animal Genetics, Edinburgh
}

The great crested newts Triturus cristatus are divided into various subspecies inhabitating different geographical areas. Of these we have experimented with three, namely, T.c. carnifex, T.c. cristatus and T.c. karelinii. Three types of hybrid $\mathrm{F}_{1}$ have been produced by natural fertilisation: karelinii (female) $\times$ cristatus (male), carnifex (female) $\times$ karelinii (male) and carnifex (female) $\times$ cristatus (male).

In contrast to the terminal chiasma localisation which is found in the $T$. vulgaris Rassenkreis, newts of the T. cristatus Rassenkreis have relatively "free " distribution of chiasmata. The $F_{1}$ hybrids, however, form roughly half the chiasmata which occur in the parent races and these are terminally localised. There is frequent failure of pairing giving rise to univalents. Inversion bridges have been observed in all the hybrids and multivalent chromosome associations in hybrids involving T.c. karelinii, indicating that the races also differ by translocations. Spermatid degeneration occurs to varying degrees in the hybrids but all succeed in forming some mature sperm.

As might be expected having regard to the cytological evidence, the backcross and $\mathrm{F}_{2}$ hybrids have proved to be weakly and heavy mortality has occurred during the larval and metamorphic stages.

\section{EQUILIBRIUM UNDER NATURAL SELECTION}

\section{J. B. S. HALDANE}

\section{Biometry Department, University College, London}

In a population in equilibrium under natural selection more than one gene can only be present at a locus if (I) There is no selective effect. (2) The population forms part of a cline. (3) The selection is balanced by mutation, or (4) Heterozygotes are fitter than homozygotes. Most natural populations are very near equilibrium, and it is contended that (4) is the most important factor conserving variance. If so, natural selection determines the variances of characters as well as their means. Since homologous characters show similar coefficients of variation 
in widely different species, heterosis must be biologically controlled. In random mating populations whose variance is due to heterosis fitness is correlated between sibs but not between parents and offspring, and the mean and variance of a character in the parents does not agree with that in the offspring, the parents being a group selected for phenotypes which are on the whole dominant. It is contended that these facts may explain the great slowness of evolution, and the apparent intensity of natural selection for certain characters in man, which may nevertheless be compatible with equilibrium.

\section{THE PARTITIONING OF THE TOTAL VARIANCE IN ALL-OR-NONE CHARACTERS}

\section{A. ROBERTSON}

Institute of Animal Genetics, Edinburgh

The analysis of all-or-none characters controlled by many pairs of genes presents some statistical difficulties. A simple analysis of variance between families as in the case of continuous variation is no longer possible. The statistical model which has to be used is that of the lexian distribution. Methods of determining the dispersion in such a distribution will be discussed and applied to data on sex-ratio. 